\title{
Exploring pre-service teachers' opportunities to learn to teach science with ICTs during teaching practice
}

\author{
Thuthukile jita
}

School of Education Studies, University of the Free State

JitaT@ufs.ac.za

(Received 24 January 2018; accepted: 24 May 2018)

\section{Abstract}

Teaching practice is an important component of the teacher education programme that provides opportunities for pre-service teachers to learn in the context of real classrooms. In this paper, I use the framework of opportunities to learn (OTL) to analyse data from a mixed-methods study on the experiences of pre-service teachers with learning to integrate Information and Communication Technologies (ICTs) into the teaching of science during teaching placement in schools. A sample of 103 science pre-service teachers from one mid-size university in South Africa completed a survey on their use of ICTs for subject teaching during teaching practice, 21 of whom submitted 33 actual lesson plans from teaching practice for analysis and participated in 4 focus group interviews. The findings show that the teacher education programme provided uneven opportunities to learn for students in the same cohort. These findings have implications for how universities should structure teaching practice experience for equitable OTL for all pre-service teachers, especially with respect to the integration of ICTs for subject teaching. Thus, I recommend restructuring of teacher education programmes to better the opportunities for future teachers to learn to use ICTs for subject teaching during and after teaching practice.

Keywords: OTL, science education, ICT, teaching practice, teacher education programme

\section{Introduction}

Teaching practice is a platform for pre-service teachers to apply the theoretical knowledge learned from their coursework in the teaching of specific subjects in schools (DarlingHammond, 2015; Kisalama \& Kafyulilo, 2012; Shulman, 1986). Literature suggests that preservice teachers tend to use ICTs for many purposes such as motivating learners, communication, basic research, and less so for improving their actual teaching of specific subject content (Cleaves \& Toplis, 2008; Kisalama \& Kafyulilo, 2012; Milner-Bolotin, 2016). The reasons for the rather low take-up of ICTs for the actual teaching of specific content and/or subjects are unclear.

Information and Communication Technologies (ICTs) in the context of this paper refer to both hardware, software, and other digital applications technologies such as computers, 
laptops, software programmes, mobile technologies, online tools, and other such e-platforms. Online tools such as emails, Facebook, and learning management systems use an Internet connection to give an opportunity to preservice teachers to communicate and provide science concepts and content in real time, thus providing a better teaching quality. In this paper I explore the development of ICT competencies of pre-service teachers on the use of these digital technologies to teach science during teaching practice. Previous studies have offered important insights on the relationships between OTL and competence to teach specific subjects by pre-service teachers (Abedi \& Herman, 2010; Cogan \& Schmidt, 2015; Hebard, 2016; Schmidt, Cogan, \& Houang, 2011). These studies demonstrate that pre-service teachers' OTL are determined not only by the number of courses taken, but also by the nature of the field experiences provided for them to practise the required skills.

Over the past two decades of curriculum change, the South African education system has focused attention increasingly on the teaching of critical subjects such as science and mathematics to improve learner performance in the subjects (Jansen, 1998; Reddy, Visser, Winnaar, Arends, Juan, Prinsloo, \& Isdale, 2016; Stols, 2013). Not enough attention, however, has been paid to the preparation of teachers to use ICT tools for teaching such subjects during teaching practice. I therefore present data on the nature and quality of the OTL extended to a cohort of South African pre-service teachers' through the entire teacher education programme including during teaching practice in schools. My study focuses on two key contributors to the pre-service teachers' OTL, specifically the on-campus coursework and the school-based teaching practice experience that enables them to integrate theory and practice in real classroom situations.

While the recently introduced Curriculum and Assessment Policy Statement (CAPS) in the Republic of South Africa (RSA) envisages teaching through ICTs for each subject, it is silent on the OTL for teachers to develop the required competence on ICT for such teaching (DBE, 2011). Khoza (2016) observes that CAPS's indication of skills, specifically related to the psychomotor domain, may even be more confusing for subject teachers since it fails to break down the type of skills that should be learned. This is in contrast to "the New Opportunities Fund (NOF) training program in the UK which was criticized as being unwieldy, over prescriptive and insufficiently geared to meet the needs of different subject specialisms" (Haydn \& Barton, 2007, p. 365) by being too definitive that ICT skills should be encouraged. It is important for ICT skills to be clearly defined for pre-service teachers without being too prescriptive. Against the background of the two contrasting approaches to the development of competence and use of ICTs for teaching as adopted in South Africa and the UK, in this paper I therefore investigate the democratic or laissez faire approach to the use of ICTs by pre-service teachers in South Africa by examining the following research questions:

- What are the pre-service teachers' OTL to teach science through ICTs as presented in the education courses offered on University campus?

- How can we make sense of the OTL to use ICTs for subject teaching and the alignment (or non-alignment) of in-class and field experiences? 


\section{Review of relevant literature}

The study on the preparation of pre-service teachers through the use of ICTs is anchored in three bodies of scholarship, specifically the literature on OTL that provides the conceptual framework, that on integrating ICTs in teacher education programmes, and that on integrating ICTs during teaching practice in school.

\section{Opportunity-to-learn (OTL) as a conceptual framework}

In the context of this paper, OTL defines whether or not pre-service teachers have had the opportunity to learn the theory of teaching a particular subject content through ICTs and also the opportunity to demonstrate competence to teach such a subject using ICTs during their teaching practice (Floden, 2002; Stevens, 1993; Wang, 1998). Most work on OTL in education focuses on in-service teachers' professional development (Jita \& Ndlalane, 2009) and on its relationship to classroom practices for specific subject areas (Hebard, 2016, Schmidt et al., 2011; Stols, 2013). The few researchers who have investigated OTL at preservice level tend to focus only on courses taken in teacher education programmes (Abedi \& Herman, 2010; Cogan \& Schmidt 2015; Hebard, 2016; Schmidt et al., 2011). While some of this research suggests a linear relationship between number of courses taken and OTL to teach a particular subject, there is more to OTL than just the coursework offered at university. In this study, I took a different approach by examining OTL from the teacher education programme in its broadest sense to include the learning offered on campus and off campus through teaching practice.

I take a multidimensional approach to OTL that examines different components such as the alignment between ICT- related modules, methodology modules in the teacher education programme, and the opportunity to observe and use ICTs during teaching practice (Wang, 1998). Such an investigation provides answers to the question of whether ICT-related modules in the teacher education curriculum give prospective science teachers the opportunity to integrate knowledge and skills on ICTs with the practical aspects of teaching their subject (e.g., science) in schools. From a social justice perspective, an important question arises as to whether all pre-service teachers have equal opportunities to transfer ICT knowledge and skills learned in their coursework to learners in different school settings as part of the pre-service teacher placement programme. This is important to explore given that teaching practice serves as an opportunity for pre-service teachers to use what they have learned in their coursework.

A key conceptual framework that influenced this study is the OTL framework as discussed in some detail in Schmidt et al. (2011). Schmidt and his colleagues argue that since the "goal of teacher education is to prepare highly competent future teachers" it is important to examine how "universities and colleges design a set of courses and experiences that presumably help to develop the necessary knowledge and skills." In their reference to previous studies on 
OTL, these scholars lament the fact that "many studies use (only) the number of courses or the kind of teacher licence to define OTL" (p. 140) thereby resulting in inconsistent findings about the effects of content in teacher education on their professional competence. Similarly, I use the OTL conceptual framework to understand how the coursework that pre-service teachers engage with leads to competence to teach in a specific subject (science). More importantly, I explore, in some depth, how the teacher education programmes provide opportunities for students to integrate ICT knowledge and skills from their coursework with the teaching practice component in the development of competence to teach science. Thus the present study goes beyond just (re)counting the number or type of ICT courses offered to preservice teachers.

A number of international studies that may provide encouragement to the SA initiatives on ICT integration show that an increase in the integration of ICTs for teaching and learning in many universities leads to improvements in student learning (Bingimlas, 2009; Haydn, 2014; Haydn \& Barton, 2007; Valtonen et al., 2015). In a recent study of teacher education students in Nigeria, Reju and Jita (2017), for example, established the importance of ICTs in improving the learning of students engaged in studying university level mathematics, especially for distance education students. Similarly, Liebenberg, Chetty, and Prinsloo (2012) and Asunka (2008) also confirmed the positive impact of ICT on distance education students in South Africa and Ghana respectively. Taking a cue from these and other research findings, the case study institution has adopted policies to integrate ICTs in teaching and learning (UFS, 2015). What remains unclear from all the studies on the integration of ICTs in the teacher education programmes, however, are issues of social justice in terms of equitable access to OTL to use the ICTs. In this study, I seek to provide a check on the issues of access and equity of opportunities to learn the ICT skills as well as the time taken to practise them during teaching practice for one cohort of students in this case study.

\section{Integration of ICT}

Many international studies, especially from developed countries in Europe and USA, have chronicled the use of ICTs for teaching and learning various subjects in schools (Ananiadou \& Claro, 2009; Bingimlas, 2009; Leask, 2013; Usun, 2009). These studies argue that the development of ICT skills for teaching cannot be divorced from the subject content taught. Thus, ICTs might, for example, be integrated with teaching and learning of science content through the use of a learning management system, collaboration with social media tools, skype, and many other appropriate tools. One major downfall in many of these studies of ICT integration is that there is a common assumption that teachers have had opportunities to learn and use ICTs during pre-service teacher training, which is not necessarily true (Hinostroza, 2018; Kirkwood \& Price, 2005; Law, Pelgrum, \& Plomp, 2008). The South African government has followed international trends by introducing various strategies and policies to close the gap on ICT knowledge and use across the different schools in the country (DHET, 2013; DoE, 2004; DTPS, 2016; Hindle, 2007). South Africa has announced ICT integration as a priority that will eventually lead its citizens to the digitisation of school classrooms. To date, however, not much is known about the chances of all pre-service teachers to learn and 
use ICTs for the teaching of specific subjects such as science, and whether they are able to be equally proactive when they are in schools during teaching practice. The main object of this study is to review opportunities provided to pre-service teachers to teach science subjects during teaching practice using ICTs. The underlying assumption is that the provision of such opportunities will provide a solid base for pre-service teachers to be competent in the integration of ICT in the teaching of science, specifically in South African classrooms.

Researchers argue that in spite of ICT-related courses being part of teacher education programmes for the preparation of teachers, there is still a concern that most graduates have almost no practical experience of using them to teach science (Bingimlas, 2009; Kisalama \& Kafyulilo, 2012). There is not much written about pre-service teachers OTL to integrate ICT skills in the real world of teaching in the schools. The major conclusion from this literature on the integration of ICTs in schools is that national curriculum policies and teacher education programmes have not gone far enough to enable the implementation of ICT policies in teaching specific subjects such as science in the higher education institutions and in schools. While the scholarship on ICT knowledge and use has improved a great deal, questions on social justice issues such as whether graduates are given equal OTL and use ICTs in schools, remain unanswered.

Future teachers need to be trained deliberately to have a solid understanding of the various ways the subject matter can be taught and assessed, especially through ICTs (Scheerens, 2016; Wiley \& Yoon, 1995). Part of this training involves pre-service teachers being given the opportunity to select the proper tools for presenting content well enough to enhance learning. The ability to operate ICT tools in addition to knowing one's subject matter are critical skills to be developed through teaching practice (Bingimlas, 2009; Higgins, 2003). The merging of ICTs and the appropriate teaching of content can best be learned in real classroom situations during teaching practice.

Pre-service teachers need not only to understand their subject matter such as science but they also have to practise the use of different technologies to best represent the content to their students in an effective manner. Thus, the context for this investigation included the teaching practice component of the teacher education programme. For many learners, especially in developing countries, science can sometimes be obscure because of the lack of appropriate specialised facilities and equipment required to demonstrate systems, processes, and reactions. This is where ICTs can become useful. For example, the use of educational software programmes such as Augmented Reality to show the functioning of a heart can suddenly open up the horizons for science students in different contexts. The ability to select and operate the appropriate ICTs, in addition to knowing the content of the subject, can suddenly add value to the quality of teaching and learning in many such science classrooms, for example. Given the various challenges of teaching science in many developing countries, including South Africa, and the possibilities arising from the rapid development of appropriate educational ICT tools, it was important for me to use science as a context for exploring the pre-service teachers' OTL and their use of ICTs for subject teaching in schools. 


\section{Methodology}

Data for this case study was collected from final-year pre-service teacher education students, across two campuses of the university, in both the Bachelor of Education (BEd) and the Postgraduate Certificate in Education (PGCE) qualifications. The case study provided rich insights on one particular university, and on a specific teacher education programme. A stratified random sample of 103 volunteer pre-service teachers studying science at all three levels of teaching, specifically the intermediate or middle school phase (IP), the senior primary and/or lower secondary phase (SP), and the senior secondary or Further Education and Training (FET) phase, completed surveys immediately after the second of the two annual teaching practice sessions. I examined 33 lesson plans from 21 participants who agreed to share them for useful themes on the use of ICTs for teaching. Focus group interviews with 4 groups of between 4 and 7 pre-service teachers were also conducted.

Data was collected during the second semester of the year over a period of three months, which, following Johnson and Onwuegbuzie (2004), Creswell (2014), and Yin (2014) allowed for in-depth exploration of the findings. The benefits of using a mixed method approach was that it provided the opportunity to test and augment the survey report with information from the lesson plans and, in line with Locke, Silverman, and Spirduso (2010), to triangulate with thick descriptions from the focus group interviews. Thus, the mixed method approach allowed for the strengths from each method used for data collection while mitigating the weaknesses in each method.

I used items from the survey to explore the OTL and use of ICTs for teaching and learning. The survey consisted of different types of questions that included demographic ones, and ones on ICT knowledge and skills predominantly learned. I used the technological pedagogical content knowledge (TPACK) instruments developed by Schmidt et al. (2009) whose reliability has previously been established by a number of other researchers. The TPACK subject teaching-related research has extensively demonstrated the validity and reliability of the TPACK survey for pre-service teachers, and it was thus not surprising to find that the instrument was reliable in the context of this study as well.

Following Creswell (2014) and Yin (2014), I took ethical issues into account and respect for the privacy of the participants and sites was paramount. The ethical clearance approval was obtained from the sampled institution and a consent form was signed by the participants prior to completing the survey. Survey participants, focus groups interviewees, as well as lesson plans were assigned unique numbers in the study to protect the names of the participants and their institution. 


\section{Data analysis}

Data was analysed according to a mixed analysis methodology. The quantitative data was cleaned, coded and entered into an Excel spreadsheet and then analysed using the SAS software (SAS, 2013). The initial descriptive analysis aimed to report on the frequencies of exposure to opportunities before qualifying as a teacher. Descriptive statistics presented data for all survey participants ( $\mathrm{N}=103)$ with no inferences (see Cohen et al., 2011).

In the qualitative phase, all lesson plans submitted were copied and the originals returned to the students. The information from each lesson plan was manually entered in an Excel sheet and coded as displayed in Table 1 below.

Table 1: Lesson planning form analysis

\begin{tabular}{|c|c|c|c|}
\hline $\begin{array}{l}\text { Lesson } \\
\text { plan }\end{array}$ & $\begin{array}{l}\text { Phase } \\
\text { (Grade) }\end{array}$ & $\begin{array}{l}\text { Which ICT tools are commonly } \\
\text { used }\end{array}$ & $\begin{array}{l}\text { How ICT tool(s) was (were) to be } \\
\text { used }\end{array}$ \\
\hline LP1 & SP (8) & PowerPoint & Lesson presentation \\
\hline LP2 & SP (8) & Scratch Pad & Not indicated \\
\hline LP4 & IP (4) & pictures, projectors, computer & Lesson presentation \\
\hline LP6 & SP (8) & PowerPoint with pictures & Lesson Presentation \\
\hline LP 7 & FET (11) & Word document/worksheet & Learner engagement \\
\hline LP 8 & IP (4) & Pictures & Learner engagement \\
\hline LP 10 & FET (11) & Images from the textbook copied & Lesson presentation \\
\hline LP 11 & FET (11) & Laptop and projector, video whiteboard. & Lesson presentation \\
\hline LP 12 & FET (11) & Video \& projector & Lesson presentation \\
\hline LP $14 *$ & FET (10) & Laptop and projector, hand out, chart & Lesson presentation \\
\hline LP 18 & FET (10) & Slides & Lesson presentation \\
\hline LP 19 & FET (10) & Hand outs & Learner engagement \\
\hline LP 20 & FET (10) & Hand outs & Learner engagement \\
\hline LP21 & FET (11) & Word document/worksheet & Lesson presentation \\
\hline LP 23 & SP (8) & Projector & Lesson presentation \\
\hline LP 25 & FET (11) & Hand out, Projector & Learner engagement \\
\hline LP 26* & FET (11) & Video \& slides & Lesson presentation \\
\hline LP 28 & SP (7) & Hand outs, pictures & Learner engagement \\
\hline LP 30 & FET (11) & poster & Presentation \\
\hline LP 31 & FET (11) & N/A & - \\
\hline LP 32 & FET (11) & Hand outs & Presentation \\
\hline LP 33 & FET (11) & N/A & - \\
\hline
\end{tabular}

*Lesson plans with missing information such the name of the school, date on which the lesson was used were removed from data capturing. 
The interview transcripts from the audiotapes were coded and categorised into various themes for developing the narrative accounts and then compared with notes taken during the interviews.

The analysis followed a "side-by-side approach where the two types of data collected were analysed separately and brought together in the convergent parallel design" (Creswell, 2014, p. 222). The initial combined data sources for the study were from a survey and focus group interviews; lesson plans analysis was further included in order to corroborate the claims and for validity and reliability purposes. Through a clear coding system and involvement of multi-method strategy during the analyses of the collected data, triangulation was implemented (see Creswell, 2014). The use of different data collection and analysis strategies complemented each other in answering the research question posed.

\section{Results}

\section{Preservice teachers' ICT knowledge and skills}

Pre-service teachers' OTL to use ICTs was explored through the survey and triangulation was done with the focus group interviews. The survey required final year pre-service teachers to indicate whether they completed any of the computer related modules offered in the teachers' education programme. Results from the survey show that most of the participants ( $N=99$ or $96.12 \%$ ) seem to have had opportunities to complete computer-related modules and only a few $(\mathrm{N}=4$ or $3.88 \%)$ had not received such opportunities in their teacher education programme. It turned out that the few students who had not completed ICT related modules had had the opportunity to learn such skills outside of the programme. These results of $3.88 \%$ $(n=4)$ were confirmed by one participant who, when asked during the focus group interviews, "What module prepared you more to start using ICT tools or resources at the university?" responded,

At the university, I did not take any computer course. There was a promotional test. I also got a chance to write that test and I was also promoted coming with my own basic knowledge on the use of computers. (Group Four, 17)

In this excerpt, the participant emphasises that he had learned ICT skills on his own. In this instance, there would have been no need for such OTL.

I further examined the sources of the pre-service teachers' ICT skills and knowledge in order to find out where ICT skills were learned. Scores were assigned to the Likert scale options as follows: "A great deal" (4); "Great extent" (3); "Some extent" (2); "Little bit" (1) and "Not at all" (0). The results from the survey are displayed in Table 2.

Table 2: Sources of ICT skills

\begin{tabular}{|l|l|l|}
\hline Items & Mean & SD \\
\hline From a school or schoolmate & 2,03 & 1,16 \\
\hline
\end{tabular}




\begin{tabular}{|l|l|l|}
\hline From university/college class & 3,02 & 0,92 \\
\hline $\begin{array}{l}\text { From a friend and/or family } \\
\text { members }\end{array}$ & 1,81 & 1,22 \\
\hline On my own & 2,81 & 1,03 \\
\hline Other, please list: & 0,09 & 0,53 \\
\hline
\end{tabular}

Table 2 shows data as closely distributed, with a small variation in the standard deviation from 0.53 to 1.22 . The source with the highest mean being "From university" $(M=3.02)$ followed by "On my own" with a mean of: $M=2.81$ while the unspecified Other has a very low mean value of 0.09 . The results were also confirmed in the focus group interviews when participants were asked, "What do you think prepared you more to start using ICT tools or resources in the first place?" Most of the responses identified the university as a source of their ICT skills as explained by one of the participants,

I only started working on computers when I got to the university because of a lack of resources at my schools. (Group One, 2)

Overall, almost all the participants in the focus group interviews concurred that the university was a major source of their ICT skills, even those participants who had an ICT skills background from school confirmed that the university resources assisted them to fine-tune their ICT skills. This observation therefore seems to confirm the argument that the teacher education programme plays an important role in equipping pre-service teachers with ICT skills competence (Twining, Raffaghelli, Albion, \& Knezek 2013). Evidently, according to the present case study, the programme turned out to be a major contributor to providing preservice teachers with the required OTL in terms of knowledge and skills. Whether those OTL were adequate to enable them to teach science through ICTs during teaching practice became the subject of further analysis in this study.

\section{Teaching practice experiences}

The lesson plans used during teaching practice were examined line-by-line, to determine which ICT tools were to be used and how they would be used. When considering the categories or themes of the data in a lesson plan, I made cross-reference to the responses from the focus group interviews to verify implementation during teaching practice as planned (see Table 3).

Table 3: Frequency of ICT tools per participant and per lesson plan

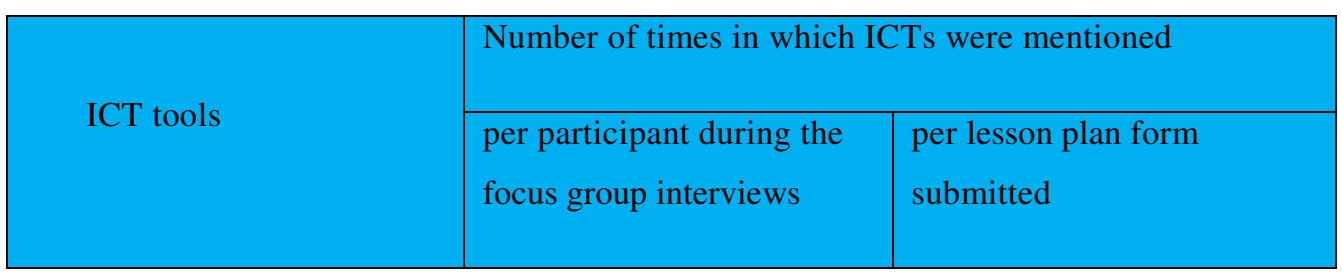




\begin{tabular}{|l|l|l|}
\hline Internet & 11 & 0 \\
\hline Mobile technology & 6 & 0 \\
\hline Projector & 8 & 8 \\
\hline Printer & 9 & 9 \\
\hline Multimedia & 15 & 5 \\
\hline Standard applications & 2 & 4 \\
\hline & & \\
\hline Computers & & 3 \\
\hline
\end{tabular}

The evidence in Table 3 suggests that multimedia, such as videos, audio, and YouTube were the most frequently mentioned ICTs, followed by the Internet; both tools were mentioned in all 4 focus group interviews. Multimedia was mentioned 15 times in the focus group interviews while in the lesson plan they were mentioned only 5 times. The Internet was mentioned 11 times as a basic tool for searching information during lesson preparation, but it was not mentioned at all in the lesson plans as an ICT tool for teaching science content. The tabulated evidence also demonstrates that printers and projectors were as commonly used as described in the focus group interviews and lesson plans. While printers serve mainly an administrative role, they contribute to effective delivery of quality lessons as diagrams, tasks, and notes can be captured beforehand to allow the teachers to focus more on conceptual development instead of note-taking or reproducing diagrams to scale, for example. In terms of OTL, these less specialised tools help to free up more time and space for content development during the science lesson. Further evidence suggested that printers might be readily available even in the schools with fewer ICT resources. For instance, one of the participants reported,

Teachers handwrote the tests and the tests were then photocopied. I also made one copy on campus and made more copies at school for my class. (Group Two, 4)

It is interesting to note that the use of mobile technology was commonly mentioned in all the focus group interviews as a common personal device used for lesson preparation and "enhancing knowledge" for pre-service teachers. The mobile devices were also frequently used for communicating with peers but they were not mentioned at all in the lesson plan forms. For example, one participant explained,

I use my phone, my USB cable and stored the information to print at school and also used a friend's laptop (Group One, 3). 
Clearly, the respondents appear to have understated the use of such mobile devices to facilitate their teaching in the lesson plans, even though the interviews suggest otherwise. The use of mobile devices may have become so routine that the pre-service teachers do not see it as an innovation or an instance of using ICTs for classroom improvement. The use of standard ICT tools such as MS Word documents and Excel sheets seem to have been used exclusively to prepare a lesson and for administrative purposes, and less for conceptual development and content exposition. The standard applications were pointed out as mostly used by mentors, only after the researcher specifically asked participants whether they had ever used the specific data management tools and how they had used them, if at all. Two participants reported,

I have seen teachers use Excel to record information like test results. I used the Word document once that is when I was displaying the rules of the lab, I wrote them on the Microsoft Word and then I printed them out and I displayed it in the class (Group Four, 17).

I used a Word document to set up the multiple-choice quiz and to assess the learners. Teachers used Excel for the attendance register (Group Three, 7).

Again, these ICTs seem to have been commonly used for data management and/or administrative purposes as opposed to facilitating content exposition. It is possible for such tools to be used for content development, for example when a teacher uses an excel file to record and analyse data from a microbial growth experiment and show the plot from such data to illustrate an exponential growth phase. Word documents can also be used to prepare draft reports and to run word searches in conceptual development. It is interesting to note that these and other ICT tools, as discussed above, which seem to have been used during teaching practice were not mentioned at all in the lesson plans. It could be that this is just an honest omission by pre-service teachers in their lesson plans though the planning and the teaching of the lesson is supposed to go together. An important message from this data is that it may be important for lesson plan templates that are used by pre-service teachers to state clearly the need for the plans to include all ICT tools used, both for administrative purposes and for content exposition, in more explicit terms. Notably though, none of the ICT tools that were identified in the lesson plans and focus group interviews were specialised tools specifically developed for teaching science topics.

The use of multimedia such as videos, audio, and YouTube were mentioned 15 times in the conversations during the focus group interviews (see Table 3) and were mostly related to the teaching of specific topics. For example, these participants pointed out,

I used the school's Internet to search and show learners for videos on YouTube while the learners watched on the screen. For example, I showed them different types of joints (Group Two, 6).

I also used Internet and watched a video on YouTube on the process of photosynthesis (Group Three, 7). 
The use of videos to deliver science content seems to be a common ICT tool among the science pre-service teachers to enhance their knowledge and for teaching. The use of videos and audio can offer exciting opportunities for pre-service teachers in preparing them to be innovative teachers (see Hartsell \& Yuen, 2006; McCullagh, Bell \& Corscadden, 2013).

\section{Discussion}

The main goal of this study was to explore pre-service teachers' OTL to teach science through ICTs prior to and during teaching practice. The OTL framework guided the study in terms of examining the balance between exposure, variety, and time available to practice with the ICTs. However, I note that teaching practice placement has variations in terms of quality on the use of ICTs for teaching and learning science in the classrooms. Different school placements lead to different experiences in mentorship and available resources for the preservice teachers, which, in turn. lead to variations in competence. These results are similar to those of the comparative study by Schmidt et al. (2011), in which variations were observed even within the teacher education programmes from the same country. Thus, there seems to be sizeable variations in the preparation of teachers from the same institution, based on their OTL to teach science content with ICT. In this case study, teaching practice seems to account for the variations in OTL and, thus, competence.

All participants in the study did their teaching practice in public schools, although the schools varied in terms of their socioeconomic status (SES). Schools in South Africa are categorised into Quintiles 1, 2 or 3, which denote schools of low SES, and Quintiles 4 and 5 that denote higher SES schools. For example, one of the participants who was placed in a Quintile 2 school, a township school, described her school context thus:

The situation was very much bad in that other school because they do not have much resources comparing to the last school I did my teaching practice. They do have a computer lab but it is not accessible, it is always locked. They do have projectors, but they said to us we will not be able to use projectors, since their walls are a little bit darker and also there are some stuff on the walls, so they say we must rely only on the textbooks and some additional sources. My friend used his own projector but when he was projecting nothing appeared there. It was disruptive or distracting to the students. (Group Four, 17)

Based on the results of the analyses of lesson plans and the focus group interviews, the variations in the OTL to use ICTs for subject teaching may be a result of the lack of standard requirements for noting ICTs in the lesson plans and perhaps the lack of appropriate ICT resources in some of the teaching practice schools. Thus, it important for teacher education programmes to conduct situation analyses of the teaching practice schools before placing preservice teachers, and partner with schools in offering ICT support to provide equal OTL to all preservice teachers to use the ICT tools during teaching practice.

On the question of how ICTs are used by pre-service teachers during teaching practice, I argue that the use is highly dependent on at least two major factors: the school's ICT 
situation; and the support or lack thereof from the mentor teachers. The findings suggest that in some of the schools there was absence of OTL or limited access to ICT tools or facilities to give pre-service teachers' OTL through ICTs. Given that many schools in South Africa, irrespective of quantile, have been provided with computers, tablets, and other ICT devices through programmes such as the South African Schoolnet, donations from the Shuttleworth Foundation, and ICT for rural development education (ICT4RED) just to mention a few (Assan \& Thomas, 2012; Dzansi \& Kofi, 2014). Therefore, I continue to draw attention to the fact that it is the absence of OTL rather than mere presence or absence of ICTs that sometimes lead to the failure of ICT integration in subject teaching in schools. Previous studies have confirmed the observation that many universities tend to invest generously in ICTs, partly to prepare their students to be globally competitive and relevant for twenty-firstcentury careers (Goktas, Yildirim, \& Yildirim, 2009; Haydn, 2014; UFS, 2015; Valtonen et al., 2015). The findings in this study thus go beyond the general findings about the state of readiness by universities to unpack the various OTL about the use of ICTs that are orchestrated within the various programmes including teacher education programme. In this study I have shown that OTL to use ICTs for subject teaching is not only limited to oncampus readiness and faculty resources but include the need to pay attention to other resources and opportunities available during school placement. If teaching practice is an important component of the teacher education programme, then its resourcing in terms of competent staff and ICT resources in this case is as important.

\section{Conclusion}

The use of ICTs in daily life and the economy have led to major developments and changes across the world. Yet, the use of ICTs remains a significant challenge for many teachers in schools and this creates a digital divide that threatens social justice and democracy in general but also presents a challenge to future teachers as they graduate and compete for jobs in the twenty-first century. In this study I aimed to establish the levels of knowledge and skills of pre-service teachers regarding ICT tools that are appropriate for teaching science during teaching practice in relation to the OTL provided through the teacher education programme.

Evidently, a vision and comprehensive plan specifically for ICT integration into subject teaching is necessary. It is important that teacher education programmes continue to play a crucial role in giving student teachers OTL to use ICT tools for subject teaching during teaching practice. Methods-based courses in the teacher education programme are not enough and we need to design lesson plan templates deliberately and carefully so that they encourage pre-service teachers to include ICT tools from the beginning stages of their training. More importantly, teacher education programmes need to be deliberate about selecting functional schools, with basic resources for teaching practice placement, and with consideration of the availability of basic ICT infrastructure and supportive mentors. Functional schools that would be able to provide necessary and appropriate support for teaching science with ICTs, if not for all subjects, need to be identified across all communities, including in rural and lowsocioeconomic settings. In some cases, it may be possible for universities and teacher education programmes to become catalysts in providing the required infrastructure, such as 
laptops and other small or transferable ICT devices to facilitate OTL using ICTs and content development through partnerships with schools and industry. The role of teacher education programme in preparing future teachers to be systematically competent in the use of ICTs for subject teaching largely depends on the available OTL including the opportunities provided by the teaching practice placement.

\section{Acknowledgement}

Support was received from the National Research Foundation (NRF) via Thuthuka Grant \# TTK150617119570.

\section{References}

Abedi, J. \& Herman, J. (2010). Assessing English language learners' opportunity to learn mathematics: Issues and limitations. Teachers College Record, 112(3), 723-746.

Ananiadou, K., \& Claro, M. (2009). 21 st century skills and competences for new millennium learners in OECD countries. Paris, France: Organization for Economic Co-operation and Development.

Assan, T., \& Thomas, R. (2012). Information and communication technology integration into teaching and learning: Opportunities and challenges for commerce educators in South Africa. International Journal of Education and Development using Information and Communication Technology (IJEDICT), 8(2), 4-16.

Asunka, S. (2008). Online learning in higher education in Sub-Saharan Africa: Ghanaian University students' experiences and perceptions. The International Review of Research in Open and Distributed Learning, 9(3). Retrieved from http://www.irrodl. org/index.php/irrodl/article/view/586/1130

Bingimlas, K. A. (2009). Barriers to the successful integration of ICT in teaching and learning environments: A review of the literature. Eurasia Journal of Mathematics, Science and Technology Education, 5(3), 235-245. Retrieved from http://www.scopus.com/inward/record.url?eid=2-s2.077950255997\&partnerID=40\&md5=9109d9b1030c8c03adf8421611810430

Cleaves, A., \& Toplis, R. (2008). Pre-service science teachers and ICT: Communities of practice? Research in Science \& Technological Education, 26(2), 203-213.

Cogan, L. S., \& Schmidt, W. H. (2015). The concept of opportunity to learn (OTL) in international comparisons of education. In K. Stacey \& R. Turner (Eds.), Assessing Mathematical Literacy (pp. 207-216). London, UK: International Publishing.

Cohen, L., Manion, L., \& Morrison, K. (2011). Research methods in education (7th ed.). London, UK: Routledge. 
Creswell, J. W. (2014). Research design. Qualitative, quantitative, \& mixed methods approach (4th ed.). Los Angeles, CA: SAGE.

Darling-Hammond, L. (2015). The flat world and education: How America's commitment to equity will determine our future. London, UK: Teachers College Press.

Department of Basic Education (DBE), (2011). Curriculum and Assessment Policy Statement (CAPS). Pretoria, South Africa: Government Printer.

Department of Education (DoE). (2004). Draft white paper on e-Education: Transforming learning and teaching through information and communication technologies (ICTs) Government Gazette No. 26734. Pretoria, South Africa. Retrieved from https://www.gov.za/documents/e-education-draft-white-paper

Department of Higher Education and Training (DHET). (2013). White paper for post-school education and training. Building an expanded, effective and integrated post-school system. Pretoria, South Africa: DHET.

Department of Telecommunication and Postal Service (DTPS). (2016). National integrated ICT policy white paper. Pretoria, South Africa: Government Printer.

Dzansi, D. Y., \& Kofi, A. (2014). Integrating ICT into rural South African schools: Possible solutions for challenges. International Journal of Science, 6(2), 341-348.

Floden, R. E. (2002). The measurement of opportunity to learn. In A. C. Porter \& A. Gamoran (Eds.), Methodological advances in cross-national surveys of educational achievement (pp. 231-266). Washington, DC: National Academy Press.

Goktas, Y., Yildirim, S., \& Yildirim, Z. (2009). Main barriers and possible enablers of ICTs Integration into pre-service teacher education programs. Educational Technology and Society, 12, 193-204.

Hartsell, T., \& Yuen, S. C. Y. (2006). Video streaming in online learning. Association for the Advancement of Computing in Education (AACE) Journal, 14(1), 31-43.

Haydn, T. (2014). How do you get pre-service teachers to become "good at ICT" in their subject teaching? The views of expert practitioners. Technology, Pedagogy and Education, 23(4), 455-469.

Haydn, T., \& Barton, R. (2007). "First do no harm": Developing teachers' ability to use ICT in subject teaching: Some lessons from the UK. British Journal of Educational Technology, 38(2), 365-368.

Hebard, H. (2016). Finding possibility in pitfalls: The role of permeable methods pedagogy in preservice teacher learning. Teachers College Record, 118(7), n7. Retrieved from https://eric.ed.gov/?id=EJ1108520 
Higgins, S. (2003). Does ICT improve learning and teaching in schools? Journal of Science and Technology, 17(6), 586-594. Retrieved from http://www.bera.ac.uk/files/reviews/ict-pur-mb-r-f-p-1aug03.pdf

Hindle, D. (2007). Guidelines for teacher training and professional development in ICT. Pretoria, South Africa: Department of Education.

Hinostroza, J. E. (2018). New challenges for ICT in education policies in developing countries: The need to account for the widespread use of ICT for teaching and learning outside the school. In I. A. Lubin (Ed.), ICT-Supported innovations in small countries and developing regions (pp. 99-119). Cham, Switzerland: Springer.

Jansen, J. D. (1998). Curriculum reform in South Africa: A critical analysis of outcomesbased education. Cambridge Journal of Education, 28(3), 321-331.

Jita, L. C., \& Ndlalane, T. C. (2009). Teacher clusters in South Africa: Opportunities and constraints for teacher development and change. Perspectives in Education, 27(1), $58-68$.

Khoza, S. B. (2016). Student teachers' reflections on their practices of curriculum and assessment policy statement. South African Journal of Higher Education, 29(4), 179197.

Kirkwood, A., \& Price, L. (2005). Learners and learning in the twenty-first century: What do we know about students' attitudes towards and experiences of information and communication technologies that will help us design courses? Studies in Higher Education, 30(3), 257-274.

Kisalama, R., \& Kafyulilo, A. C. (2012). Developing pre-service teachers' technology integration competencies in science and mathematics teaching: Experiences from Tanzania and Uganda. Makerere Journal of Higher Education, 3(2), 99-113.

Law, N., Pelgrum, W. J., \& Plomp, T. (2008). Pedagogy and ICT use in schools around the world: Findings from the IEA SITES 2006 study. CERC Studies in Comparative Education, 23, 263-277. https://doi.org/10.1007/978-1-4020-8928-2

Leask, M., \& Pachler, N. (2013). Learning to teach using ICT in the secondary school: A companion to school experience. London, UK: Routledge.

Liebenberg, H., Chetty, Y., \& Prinsloo, P. (2012). Student access to and skills in using technology in an open and distance learning context. The International Review of Research in Open and Distributed Learning, 13(4), 250-268.

Locke, L. F., Silverman, S. J., \& Spirduso, W. W. (2010). Reading and understanding research. Los Angeles, CA: SAGE. 
McCullagh, J. F., Bell, I., \& Corscadden, F. (2013). How does video analysis support student teachers in the very early stages of their initial teacher education? Teacher Education Advancement Network Journal (TEAN), 5(3), 39-51.

Milner-Bolotin, M. (2016). Rethinking technology-enhanced physics teacher education: From theory to practice. Canadian Journal of Science, Mathematics and Technology Education, 16(3), 284-295.

Reddy, V., Visser, M., Winnaar, L., Arends, F., Juan, A., Prinsloo, C., \& Isdale, K. (2016). TIMSS 2015: Highlights of Mathematics and Science Achievement of Grade 9 South African learners-Human Sciences Research Council. Retrieved from http://www.che.ac.za/sites/default/files/TIMSS 2015 Grade 5 Highlights document.pdf

Reju, C., \& Jita, L. C. (2017). Technology and its relationships with distance and online learning constructs in undergraduate mathematics in Nigeria. Paper presented at the ISTE UNISA Conference, Kruger National Park, South Africa.

Scheerens, J. (Ed.). (2016). Opportunity to learn, curriculum alignment and test preparation: A research review. New York, NY: Springer.

Schmidt, D. A., Baran, E., Thompson, A. D., Mishra, P., Koehler, M. J., \& Shin, T. S. (2009). Technological pedagogical content knowledge (TPACK): The development and validation of an assessment instrument for pre-service teachers. Journal of Research on Technology in Education, 42(2), 123-149.

Schmidt, W. H., Cogan, L., \& Houang, R. (2011). The role of opportunity to learn in teacher preparation: An international context. Journal of Teacher Education, 62, 138-153.

Shulman, L. S. (1986). Those who understand: Knowledge growth in teaching. Educational Researcher, 15(2), 4-14.

South African Statistics (SAS) Institute. (2013). SAS/STAT 13.1: User's Guide. Cary, NC: SAS Institute.

Stevens, F. I. (1993). Applying an opportunity-to-learn conceptual framework to the investigation of the effects of teaching practices via secondary analyses of multiplecase-study summary data. The Journal of Negro Education, 62(3), 232-248.

Stols, G. (2013). An investigation into the opportunity to learn that is available to Grade 12 mathematics learners. South African Journal of Education, 33(1), 1-18.

Twining, P., Raffaghelli, J., Albion, P., \& Knezek, D. (2013). Moving education into the digital age: The contribution of teachers' professional development. Journal of Computer Assisted Learning, 29(5), 426-437. 
Usun, S. (2009). Information and communications technologies (ICT) in teacher education (ITE) programs in the world and Turkey: A comparative review. Procedia-Social and Behavioral Sciences, 1(1), 331-334.

Valtonen, T., Kukkonen, J., Kontkanen, S., Sormunen, K., Dillon, P., \& Sointu, E. (2015). The impact of authentic learning experiences with ICT on pre-service teachers' intentions to use ICT for teaching and learning. Computers \& Education, 81, 49-58.

Wang, J. (1998). Opportunity to learn: The impacts and policy implications. Educational Evaluation and Policy Analysis, 20(3), 137-156.

Wiley, D. E., \& Yoon, B. (1995). Teacher reports on opportunity to learn: Analyses of the 1993 California Learning Assessment System (CLAS). Educational Evaluation and Policy Analysis, 17(3), 355-370. 